\title{
Financial Leverage, Educational-Level Faultline Strength and Strategic Change: Evidence from China
}

\author{
Dan Liu ${ }^{1} \&$ Qun-zhu Wang ${ }^{1}$ \\ Management School, Shandong Technology and Business University, Yantai, China \\ Correspondence: Qun-zhu Wang, Management School, Shandong Technology and Business University, Yantai, \\ China. E-mail: 18447056140@163.com
}

Received: July 23, 2021

doi:10.5539/ijbm.v16n10p104
Accepted: September 18, 2021

Online Published: September 29, 2021

URL: https://doi.org/10.5539/ijbm.v16n10p104

\begin{abstract}
With the improvement of financial leverage, enterprises will face more severe financial difficulties and more stringent external supervision. Enterprises tend to take a high-intensity strategic change to get rid of the trouble. Taking China's A-share manufacturing listed companies from 2008-2018 as the research sample, based on the theory of enterprise behavior and faultlines theory, this paper explores the impact of corporate financial leverage on strategic change and the moderating effect of the top management team (TMT) educational-level faultine strength. The results show that there is a positive correlation between corporate financial leverage and strategic change. TMT educational-level faultline strength negatively moderates the positive correlation between corporate financial leverage and strategic change. The existence of an educational-level faultline makes it difficult for the whole TMT to form a consensus of change. Our study suggests that improving the matching degree of education characteristics of TMT is the basic condition for enterprises to implement high-intensity strategic change.
\end{abstract}

Keywords: financial leverage, educational-level faultline strength, strategic change

\section{Introduction}

In response to the global economic crisis, China issued a 4 trillion economic stimulus policy in 2008. Since then, under the "debt-investment" driven development model, the financial leverage of enterprises has continued to rise. In 2015, China's supply-side structural reform task put forward the requirement of lowering the lever. However, in recent years, the global economic downturn has led to the rise of trade protectionism, the continuing economic and trade frictions between China and the United States, and the impact of the "new corona pneumonia epidemic" at the end of 2019, under the pressure of "maintaining growth", enterprises' financial leverage remains high. High financial leverage not only leads to difficult capital turnover and increased debt risk but also reduces corporate performance (Zhou et al., 2021). As the so-called "poverty will change", most enterprises expect to solve the dilemma through strategic change. Strategic change has become a significant choice for enterprises to deal with the uncertain environment (Mackey \& Chia, 2013). But at the same time, the implementation of strategic change is subject to the constraints of their financial situation, how will the rise of corporate financial leverage affect the strategic change? Answering this question will have practical significance to appreciate the choice of high leverage enterprises.

Moreover, upper echelons hold that the strategic decision-making of TMT is affected by their cognitive level and professional ability. The difference in educational level makes them inconsistent in cognition, skills, and risk preference, which may cause TMT to hold different attitudes towards strategic change decision-making (Hambrick \& Mason, 1984). The impact of education level on TMT strategic decisions varies. The reason for the contradictory conclusion may be that the relevant research only focuses on the single feature of educational heterogeneity, without considering the combined impact of tenure, functional background, and other characteristics on TMT strategic decision-making. Lau and Murnighan (1998) created the faultlines theory to remedy this deficiency, indicating that the faultlines is composed of a set of virtual boundaries that divide TMT into different subgroups based on educational level, tenure, and functional background. The higher the boundary overlaps, the greater strength of the faultlines. Based on the three characteristics of education level, tenure, and functional background, we comprehensively measure educational-level faultline strength and explore how educational-level faultline strength regulates strategic change in the case of rising corporate financial leverage, to 
make up for the defect of only considering the heterogeneity of education level.

There are two main contributions to this paper. First, by exploring the impact of financial leverage on corporate strategic change, the theory of the antecedents of corporate strategic change is enriched. Second, to make up for the shortcomings of previous studies that only examined the impact of TMT characteristics on strategic decision-making from a single dimension, the three characteristics of comprehensive education level, tenure, and functional background in educational-level faultline strength measure the differences of TMT as a whole, which can more scientifically explain their impact on corporate strategic change decisions.

\section{Literature Review}

\subsection{Financial Leverage and Strategic Change}

Previous studies on the antecedents of corporate strategic change mostly focus on CEO characteristics (Herrmann \& Nadkarni, 2013; Weng \& Lin, 2014), performance feedback (Tarakci et al., 2018), environmental dynamics (Richard et al., 2019), and other factors. These studies mostly focus on the role of corporate decision-making and external macro factors but ignore the impact of the corporate financial situation.

Studies have shown that high leverage increases corporate capital costs and reduces disposable cash flows, thereby increasing corporate debt risk, reducing profitability, and increasing bankruptcy risk (Tao et al., 2020). Enterprises in financial difficulties and poor operating conditions need to adjust the allocation of resources to cope with difficulties and reshape the relation to external resources to avoid the risk of acquisition or bankruptcy. Therefore, it is reasonable to infer that high leverage enterprises in a debt crisis will have deeply strategic change motivation, alleviate the threat of survival and seek better development.

\subsection{Education Level Heterogeneity and Faultline Theory}

Previous scholars have studied the impact of TMT's education level on strategic decision-making from the perspective of heterogeneity, resulting in different conclusions on the impact of education level on TMT's strategic decision-making. Tzabbar and Margolis (2017) believed that the enhancement of educational heterogeneity can bring more diversified information to the team, which is conducive to the formulation of strategic change decisions. Lee et al. (2021) believed that the high heterogeneity of education level is not conducive to the fit of TMT's strategic concepts, and will hinder the implementation of strategic changes in enterprises. But the impact of executive decision-making is not only a single feature, but also a variety of features overlap.

Lau and Murnighan (1998) initiated faultline theory to compensate for heterogeneity. The theory holds that teams with significant faultline strength are more likely to form substantive subgroups based on a certain feature classification, thus generating new interaction patterns and influencing the process and results of decision-making. Compared with the traditional team heterogeneity research, the advantage of this theory is that it can achieve the overall measurement of multiple characteristics of TMT members and reflect the overall influence of multiple characteristics such as TMT tenure, education level, and functional background.

\section{Research Hypotheses}

\subsection{Effect of Financial Leverage on Strategic Change}

Based on the theory of enterprise behavior, when the financial leverage is too high to make the enterprise encounter financial difficulties or face bankruptcy risk, the enterprise will re-examine the current strategic choice, find loopholes through problem searching, and adjust the current improper strategy to reverse the unfavorable situation of the enterprise (Cyert \& March, 1963).

Specifically, on the one hand, the increase of financial leverage will make enterprises face financial difficulties. Excessive leverage ratio makes liabilities account for a large proportion of the capital structure, and enterprises need to bear greater pressure on repayment of capital and interest. The rise of financial costs makes it more difficult for enterprises to refinance, and finally, they fall into financial difficulties. The emergence of financial distress reflects the poor management of enterprises, and the internal capital flow can not support the normal operation of enterprises. To avoid more serious losses caused by financial distress, enterprises have to start to try new strategies to "save resources and flow"(Iqbal et al., 2020). On the other hand, the increase of financial leverage will aggravate the bankruptcy risk of enterprises. High- interest costs and the widespread phenomenon of "short debt and long investment" in enterprises easily lead them into the vicious circle of "borrowing new to repay the old" and "borrowing new to repaying the interest by borrowing new", leading to the continuous decline in the stability of capital increase in the risk of bankruptcy (DeAngelo et al., 2018). Facing bankruptcy means that there are problems in the current resource allocation, financial management, and other aspects of the 
enterprise. If the current development strategy continues to be maintained, it may lead to irreparable consequences. At this time, enterprises urgently need to strengthen strategic change to improve their situation to strive for improvement in the future.

In addition to causing financial distress and bankruptcy risk, high leverage enterprises will also cause more external supervise, and the pressure brought by excessive supervision will also strengthen the motivation of corporate strategic change. Barattieri et al. (2021) pointed out that the high leverage of enterprises will be highly concerned by government departments, banks, and other institutional investors institutions. For example, banks and other institutions will not renew high debt enterprises for risk aversion, which makes these enterprises face a more unfavorable situation (Kim et al., 2018). Kadous et al. (2019) found that the risk of corporate debt default caused by high leverage will increase the supervision of auditors. The greater the financial distress, the stronger the external supervision of auditors, which causes a certain degree of operating pressure to enterprises. In the case of external supervision and financing difficulties, enterprises facing financial difficulties urgently need to release the signal of strategic change to the outside world to show their self-help position in order to continue to obtain the support of external funds (Zhang, 2020).

H1: Corporate financial leverage is positively correlated with the intensity of strategic change.

\subsection{The Moderating Effect of Educational-Level Faultline Strength}

The influence of team faultline strengths on the decision-making process and results of the TMT team is mainly carried out by studying the interaction state of its formed subgroups. At present, there are mainly two views in the academic circle. One view is based on the social identity theory (Carton \& Cummings, 2012), the social classification theory (Thatcher \& Patel, 2012), and the similarity attraction theory (Van \& Mell, 2016), that focusing on the interaction process of internal absorption and external exclusion of subgroups. It is believed that the existence of faultlines will be not conducive to the communication between subgroups, which is difficult to reach a consensus. Another view is based on information processing theory (Carton \& Cummings, 2012), focusing on the sharing and transmission process of information between different subgroups, that the existence of faultlines will help improve the quality of decision-making of TMT. Based on the above two views, what impact will the existence of educational-level faultline strength have on the relationship between financial leverage and strategic change? Is it promotion or inhibition? This article will discuss from two angles.

Based on the first view, educational-level faultline strength will expand the differences in TMT's perception of financial risks, which results in conflicts and confrontations between different views within the team, which maks it difficult for TMT to reach a consensus on strategic change. According to social identity theory, when there is an educational-level faultline, the subgroups with the same or similar educational level will have higher homogeneity in terms of cognitive level, professional experience, and value concept. There are more differences in the knowledge level and values among children with different educational levels. This difference will lead TMT to identify with their sub-groups and exclude other sub-groups (Liu et al., 2019), increase distrust among sub-groups, reduce communication and communication between them, and hinder the sharing of knowledge and information within the TMT team (Huteschenreuter \& Horstkotte, 2013). In severe cases, it will also cause conflicts among sub-groups. In this case, it is difficult for TMT from different sub-groups to sit down carefully to discuss the financial leverage dilemma faced by enterprises, and their understanding of the problem is limited to their small circles. Due to the inability to absorb multiple views among sub-groups, there is a lack of in-depth discussion of options, which will seriously hinder the formulation and implementation of strategic change decisions (Richard et al, 2019). Based on this, this paper argues that when the increase in corporate financial leverage leads to corporate financial distress and bankruptcy risk, although enterprises urgently need to turn the crisis into safety by strengthening strategic change at this time, the existence of educational-level faultline strength makes it difficult for a senior management team to reach agreement on strategic change, which will weaken the intensity of strategic change of enterprises.

Based on the second view, educational-level faultline strength promotes the sharing and transmission of knowledge, which makes TMT have more choices and more sufficient preparations in exploring solutions to corporate financial distress, and thus are more inclined to strengthen strategic change. Specifically, the process of promoting strategic decision-making by educational-level faultine strength is mainly reflected in three aspects. First, since each sub-group has its unique knowledge and experience, this knowledge-based fracture provides trust and a comfortable environment for sub-groups to share key skills (Carton \& Cummings, 2012). Second, the full integration of knowledge and experience among the subgroups of the sharing mechanism in an appropriate environment helps TMT make comprehensive and high-quality decisions by seeking common ground and reserving differences in different opinions. Third, educational-level faultline strength can promote consensus 
among different subgroups on final strategic decisions through communication mechanisms, thereby improving the efficiency of decision implementation (Chung et al., 2015). Accordingly, when enterprises face excessive financial leverage and need to take change measures to alleviate the dilemma, educational-level faultline strength enables the full integration of different knowledge and experience among sub-groups in a comfortable environment through sharing and communication mechanisms. Different sub-groups actively contribute to the debt crisis and form a variety of solutions, which will enhance the confidence of enterprises to get rid of the dilemma through strategic change and further strengthen strategic change. In summary, this paper proposes two competitive assumptions:

H2a: Educational-level faultline strength negatively moderates the positive correlation between financial leverage and corporate strategic change.

$\mathrm{H} 2 \mathrm{~b}$ : Educational-level faultline strength positively moderates the positive correlation between financial leverage and corporate strategic change.

\section{Sample, Variable Measurement, and Model Design}

\subsection{Sample and Data Sources}

This paper takes Shanghai and Shenzhen A-share manufacturing listed companies from 2008 to 2018 as research samples. To ensure the quality of data, the sample processing is as follows: Delete the ST, * ST listed companies during the study period. Delete samples with serious missing data. After the screening, 10165 valid unbalanced panel data is retained. The data used in this paper is all from the China Stock Market and Accounting Research (CSMAR) database. The data processing is completed by Excel and Stata 16.0.

\subsection{Variables Measurement}

\subsubsection{Measurement of Financial Leverage}

Financial leverage $\left(\operatorname{Lev}_{i, t-1}\right)$ is an indicator of corporate debt risk. As a double-edged sword, maintaining a reasonable level of leverage will increase corporate earnings, but too high will lead to an increase in debt risk. Most studies use asset-liability ratios to measure corporate financial leverage, which is an important action reference for external investors and internal managers. Using this indicator can better capture the impact of financial leverage on corporate behavior (Harford et al., 2009). We also draws on this method to use the asset-liability ratio to measure the financial leverage of enterprises, that is, financial leverage $=$ total liabilities / total assets.

\subsubsection{Measurement of Strategic Change}

The intensity of strategic change $\left(S t r_{i, t}\right)$ refers to the volatility of corporate core strategic resources in the annual interval, which can reflect the degree of reallocation of key resources by enterprises. Consistent with previous work (Oehmichen et al., 2017; Triana et al., 2014), we computed a composite measure of strategic change using six strategic allocation dimensions: (a) advertising intensity (advertising/sales), (b) research and development $(R \& D)$ intensity (R\&D/sales), (c) plant and equipment upgrades (new plant and equipment/gross plant and equipment), (d) nonproduction overhead(administration/sales), (e) inventory levels (inventory/sales), and (f) financial leverage (debt/equity). Next, the differences between the year $t$ and the year $t-1$ of the above six dimensions are calculated, and the difference is adjusted based on the industry median. The adjustment method is to use the difference to subtract the industry median. We then standardize the adjusted changes based on industry and year and take absolute values of the results. Finally, we add the results of the previous step to the average, used the final average to measure the intensity of strategic change. The larger the average is, the greater the intensity of strategic change.

\subsubsection{Measurement of Educational-Level Faultline Strength}

This paper selects the FLS model proposed by Shaw (2004) to measure educational-level faultline strength $\left(\right.$ Flsedu $\left._{i, t-1}\right)$, which believes that team members can form multiple subgroups based on a certain feature. This model can calculate the possibility of team members forming subgroups based on a single feature. This method is more suitable for this paper only considering educational-level faultline strength. The calculation formula of educational-level faultline strength is:

$$
\text { Flsedu }_{\mathrm{i}, \mathrm{t}-1}=\mathrm{IA} \times(1-\mathrm{CGAI})
$$

Among them, IA represents the consistency of the other characteristics of the internal staff of the sub-group except for the characteristics of education level, CGAI represents the consistency of the other characteristics of the sub-group except for the characteristics of education level, and Flsedu $\mathrm{i}_{\mathrm{t}-1}$ is the final calculated educational-level faultline strengths. It can be seen from the formula that educational-level faultline strength is 
positively correlated with the internal consistency IA of the subgroup, and negatively correlated with the consistency CGAI among the subgroups. It shows that in addition to the characteristics of education level, the more consistent in other attributes within the subgroup, and the more inconsistent in other attributes among the subgroups, the greater the intensity of educational-level faultline strength.

Compared to the surface features (e.g., gender, age, and race) that are more easily observed and identified, that represent the deep features(e.g., education level, tenure, and functional background) can better reflect the differences in the experience, cognition, and knowledge level of TMT. Moreover, the faultline strengths formed by the deep features can have a more prominent impact on senior executives, while the impact of surface features will gradually weaken or even disappear over time (Kaczmarek et al., 2012). So we select the level of education, tenure, function background comprehensive measure of educational-level faultline strength. Since the FLS model can solely calculate the classification variables, it is necessary to classify the education level, tenure, and functional background of TMT. Referring to the methods of Richard et al. (2019) and Chung et al. (2015), education-level is divided into four categories: doctorate, master's degree, undergraduate, and others, with values of $4,3,2$, and 1 . TMT tenure is divided into less than 3 years, more than 3 years but less than 6 years, and more than 6 years, assigned 1,2,3. The function background is divided into three categories: the output function, the conversion function, and the support function. Sales and R\&D are classified as the output function, production, operation, and manufacturing classified as the conversion function, and the rest are not classified as the support function, assigned $1,2,3$.

\subsubsection{Control Variables}

Referring to previous studies on relevant fields (Richard et al., 2019; Chung et al., 2015), we choose enterprise age $\left(\mathrm{Age}_{\mathrm{i}, t-1}\right)$, enterprise size $\left(\mathrm{Size}_{\mathrm{i}, t-1}\right)$, return on assets $\left(\mathrm{Roa}_{\mathrm{i}, t-1}\right)$, ownership concentration $\left(\mathrm{Fir}_{\mathrm{i}, \mathrm{t}-1}\right)$ and equity balance degree $\left(\operatorname{Dr}_{1, t-1}\right)$ as control variables, and set year and industry dummy variables. The measurement methods of all variables are shown in Table 1.

Table 1. Variable definition table

\begin{tabular}{|c|c|c|}
\hline Name & Variables & Definition \\
\hline $\mathrm{STR}_{\mathrm{i}, \mathrm{t}}$ & Strategic change & The fluctuation degree of enterprise core strategic resource allocation in the annual interval \\
\hline $\mathrm{LEV}_{\mathrm{i}, \mathrm{t}-1}$ & Financial leverage & Total liabilities / Total assets. \\
\hline FLSEDU $_{\mathrm{i}, \mathrm{t}-1}$ & $\begin{array}{l}\text { Educational-level faultline } \\
\text { strength }\end{array}$ & Flsedu=IA* (1-CGAI $)$ \\
\hline $\mathrm{AGE}_{\mathrm{i}, \mathrm{t}-1}$ & Firm age & The difference between the year $t$ of sample enterprises and the year of company establishment \\
\hline $\mathrm{SIZE}_{\mathrm{i}, \mathrm{t}-1}$ & Firm size & The natural logarithm of the total assets at the end of the sample enterprise \\
\hline $\mathrm{ROA}_{\mathrm{i}, \mathrm{t}-1}$ & Return on assets & Net profit / Total assets \\
\hline $\mathrm{FIR}_{\mathrm{i}, \mathrm{t}-1}$ & Ownership concentration & Shareholding ratio of the largest shareholder / Total corporate equity \\
\hline $\mathrm{DR}_{\mathrm{i}, \mathrm{t}-1}$ & Equity balance degree & Total number of second to tenth shareholders / Total number of first shareholders \\
\hline INDUS & Industry & Dummy variable \\
\hline YEAR & Year & Dummy variable \\
\hline
\end{tabular}

\subsection{Model Design}

In order to test the impact of corporate financial leverage on strategic change and determine whether the results meet the prediction of hypothesis $\mathrm{H} 1$, this paper constructs a regression model (2).

$$
\operatorname{Str}_{\mathrm{i}, \mathrm{t}}=\alpha_{0}+\alpha_{1} \operatorname{Lev}_{\mathrm{i}, \mathrm{t}-1}+\alpha_{2} \mathrm{Age}_{\mathrm{i}, \mathrm{t}-1}+\alpha_{3} \operatorname{Size}_{\mathrm{i}, \mathrm{t}-1}+\alpha_{4} \operatorname{Roa}_{\mathrm{i}, \mathrm{t}-1}+\alpha_{5} \operatorname{Fir}_{\mathrm{i}, \mathrm{t}-1}+\alpha_{6} \operatorname{Dr}_{\mathrm{i}, \mathrm{t}-1}+\Sigma \text { Indus }_{\mathrm{i}, \mathrm{t}}+\Sigma \text { Year }+\varepsilon_{\mathrm{i}, \mathrm{t}}
$$

To test the moderating effect of educational-level faultline strength on the main model, the moderating variable and interaction term is introduced based on model (2) to construct model (3) to determine which hypothesis H2a and $\mathrm{H} 2 \mathrm{~b}$ are more realistic, as follows:

$$
\begin{aligned}
& \text { Stri }_{i, t}=\alpha_{0}+\alpha_{1} \operatorname{Lev}_{\mathrm{i}, \mathrm{t}-1}+\alpha_{2} \text { Flsedu }_{\mathrm{i}, \mathrm{t}-1}+\alpha_{3} \operatorname{Lev} \times \text { Flsedu }_{\mathrm{i}, \mathrm{t}-1}+\alpha_{4} \text { Age }_{\mathrm{i}, \mathrm{t}-1}+\alpha_{5} \operatorname{Size}_{\mathrm{i}, \mathrm{t}-1}+\alpha_{6} \text { Roa }_{\mathrm{i}, \mathrm{t}-1}+\alpha_{7} \text { Fir }_{\mathrm{i}, \mathrm{t}-1}+\alpha_{8} \operatorname{Dr}_{\mathrm{i}, \mathrm{t}-1} \\
& +\sum \text { Indus }_{i, t}+\Sigma \text { Year }+\varepsilon_{i, t}
\end{aligned}
$$

\section{Empirical Results}

\subsection{Descriptive Statistics}

Table 2 shows the descriptive statistical results of all variables. According to the data in the table, the average value of strategic change (Str) is 0.484 , the minimum value is 0.085 , and the maximum value is 2.319 , which 
reflects that there are significant differences in the strategic change intensity of each sample enterprise. The average value of financial leverage $(\mathrm{Lev})$ of enterprises is 0.407 , and the maximum value is 0.896 , indicating that the average financial leverage of enterprises is maintained at about $40 \%$, but some enterprises are close to $90 \%$, facing severe financial difficulties. The average value of Flsedu is 0.084 , and the maximum value is 0.284 . It represents that the possibility of forming Flsedu between different enterprises is fairly different.

Table 2. The descriptive statistics of main variables

\begin{tabular}{llllll}
\hline VARIABLES & $\mathrm{N}$ & MEAN & SD & MIN & MAX \\
\hline STR & 10165 & 0.484 & 0.389 & 0.085 & 2.319 \\
LEV & 10165 & 0.407 & 0.195 & 0.051 & 0.896 \\
FLSEDU & 10165 & 0.084 & 0.071 & 0 & 0.284 \\
FIR & 10165 & 0.232 & 0.124 & 0.023 & 0.553 \\
DR & 10165 & 0.915 & 0.777 & 0.045 & 4.108 \\
SIZE & 10165 & 22.041 & 1.13 & 19.895 & 25.389 \\
ROA & 10165 & 0.044 & 0.058 & -0.165 & 0.221 \\
AGE & 10165 & 15.85 & 5.253 & 4 & 30 \\
\hline
\end{tabular}

\subsection{Correlation Analysis}

Table 3 shows the results of the correlation analysis of variables. According to the results, it can be seen that corporate financial leverage is significantly correlated with strategic change $(p<0.01)$, which preliminarily verifies the hypothesis $\mathrm{H} 1$. That is, with the increase of financial leverage, the intensity of strategic change will increase. There is a significant negative correlation between educational-level faultline strength and strategic change intensity $(\mathrm{p}<0.05)$, indicating that the existence of educational-level faultline strength may be more likely to weaken the strategic change intensity of enterprises. Additionally, the age and scale are significantly negatively correlated with strategic change, which may be due to the growth of the enterprise's established years and the expansion of the scale, it is easier to form strategic inertia within the enterprise, and more inclined to respond to changes according to the inherent mode, thus reducing the intensity of strategic change in their enterprise.

Table 3. Correlation analysis of main variables

\begin{tabular}{|c|c|c|c|c|c|c|c|c|}
\hline variables & (1) & (2) & (3) & (4) & (5) & (6) & (7) & (8) \\
\hline (1) $S T R_{i, t}$ & 1.000 & & & & & & & \\
\hline (2) $L E V_{i, t-1}$ & $0.097 * * *$ & 1.000 & & & & & & \\
\hline (3)FLSEDU $U_{i, t-1}$ & $-0.018^{* *}$ & $-0.058^{* * *}$ & 1.000 & & & & & \\
\hline (4) $F I R_{i, t-1}$ & $0.027 * * *$ & $-0.230^{* * *}$ & $0.083 * * *$ & 1.000 & & & & \\
\hline (5) $D R_{i, t-1}$ & $0.035 * * *$ & $-0.141^{* * *}$ & $0.045^{* * *}$ & $0.770 * * *$ & 1.000 & & & \\
\hline (6) $A G E_{i, t-1}$ & $-0.019 * *$ & $0.133 * * *$ & $-0.067 * * *$ & $-0.108 * * *$ & -0.012 & 1.000 & & \\
\hline (7) $S I Z E_{i, t-1}$ & $-0.116^{* * *}$ & $0.484 * * *$ & $-0.036^{* * *}$ & $-0.120 * * *$ & $-0.091 * * *$ & $0.170^{* * *}$ & 1.000 & \\
\hline (8) $R O A_{i, t-1}$ & $-0.202 * * *$ & $-0.388 * * *$ & $0.033 * * *$ & $0.162 * * *$ & $0.032 * * *$ & $-0.067 * * *$ & -0.005 & 1.000 \\
\hline
\end{tabular}

\subsection{Regression Analysis}

To make the results of model estimation more effective, before the formal regression, the sample data are processed as follows: (1) All continuous variables $0-1 \%$ and $99-100 \%$ of the sample data are reduced to eliminate the influence of a few extreme values. (2) To avoid the possible multicollinearity between interaction terms and explanatory or moderator variables, the explanatory and moderator variables are centralized before the interaction terms are constructed. (3) The variance expansion factor test results of explanatory variables and all control variables reveal the mean value of VIF is 1.66, and the VIF values of each variable are less than 3, far less than the standard of 10 , indicating that there is no multicollinearity between variables. (4) After the Hausman test, the P-value tends to 0 , and the test results reject the original hypothesis, that's why the fixed effect model is finally selected. (5) We delay the main continuous variables by one stage to address the endogenous effects. 
According to the results of table 4, model(2) demonstrates the regression coefficient between financial leverage $\left(\operatorname{Lev}_{\mathrm{i}, \mathrm{t}-1}\right)$ and strategic change $\left(\operatorname{Str}_{\mathrm{i}, \mathrm{t}-1}\right)$ is 0.258 , which is significant at the level of $1 \%$, and the regression coefficient is still significant at the level of $1 \%$ after model (3) adding moderators and model (4) introducing interactivity, which indicates that there is a significant positive correlation between financial leverage and strategic change, assuming that $\mathrm{H} 1$ is verified.

According to the regression results of model (4), the regression coefficient of interaction (Lev $\times$ Flsedu $\left.u_{i, t-1}\right)$ and strategic change $\left(\operatorname{Str}_{i, t-1}\right)$ is -0.766 , and it is significant at the level of $1 \%$, while the regression coefficient of financial leverage $\left(\operatorname{Lev}_{\mathrm{i}, \mathrm{t}-1}\right)$ and strategic change is 0.255 , and it is significant at the level of $1 \%$. The symbol of the two coefficients is opposite, indicating that educational-level faultline strength plays a negative regulatory role between financial leverage and strategic change, and verifies hypothesis H2a.

Table 4. The regression result

\begin{tabular}{|c|c|c|c|c|}
\hline VARIABLES & MODEL(1) & MODEL(2) & MODELl(3) & MODEL(4) \\
\hline \multirow[t]{2}{*}{$\mathrm{FIR}_{\mathrm{i}, \mathrm{t}-1}$} & $-0.177 * *$ & -0.088 & -0.088 & -0.088 \\
\hline & $(0.079)$ & $(0.08)$ & $(0.08)$ & $(0.08)$ \\
\hline \multirow[t]{2}{*}{$\mathrm{DR}_{\mathrm{i}, \mathrm{t}-1}$} & $0.039 * * *$ & $0.035 * *$ & $0.035 * *$ & $0.034 * *$ \\
\hline & $(0.014)$ & $(0.014)$ & $(0.014)$ & $(0.014)$ \\
\hline \multirow[t]{2}{*}{ SIZE $_{i, t-1}$} & $-0.109 * * *$ & $-0.131 * * *$ & $-0.131 * * *$ & $-0.131 * * *$ \\
\hline & $(0.01)$ & $(0.01)$ & $(0.01)$ & $(0.01)$ \\
\hline \multirow[t]{2}{*}{$\mathrm{ROA}_{\mathrm{i}, \mathrm{t}-1}$} & $-1.316^{* * *}$ & $-1.178 * * *$ & $-1.179 * * *$ & $-1.182 * * *$ \\
\hline & $(0.085)$ & $(0.087)$ & $(0.087)$ & $(0.087)$ \\
\hline \multirow[t]{2}{*}{$\mathrm{AGE}_{\mathrm{i}, \mathrm{t}-1}$} & -0.01 & -0.003 & -0.003 & -0.004 \\
\hline & $(0.015)$ & $(0.015)$ & $(0.015)$ & $(0.015)$ \\
\hline \multirow[t]{2}{*}{$\operatorname{LEV}_{\mathrm{i}, \mathrm{t}-1}$} & & $0.258 * * *$ & $0.257 * * *$ & $0.255 * * *$ \\
\hline & & $(0.039)$ & $(0.039)$ & $(0.039)$ \\
\hline \multirow[t]{2}{*}{ FLSEDU $_{\mathrm{i}, \mathrm{t}-1}$} & & & -0.046 & -0.036 \\
\hline & & & $(0.059)$ & $(0.059)$ \\
\hline \multirow[t]{2}{*}{$\mathrm{LEV} \times \mathrm{FLSEDU}_{\mathrm{i}, \mathrm{t}-1}$} & & & & $-0.766 * * *$ \\
\hline & & & & $(0.279)$ \\
\hline \multirow[t]{2}{*}{ CONS } & $3.025 * * *$ & $3.302 * * *$ & $3.306 * * *$ & $3.303 * * *$ \\
\hline & $(0.264)$ & $(0.266)$ & $(0.267)$ & $(0.266)$ \\
\hline INDUS & CONTROL & CONTROL & CONTROL & CONTROL \\
\hline YEAR & CONTROL & CONTROL & CONTROL & CONTROL \\
\hline $\mathrm{N}$ & 10165 & 10165 & 10165 & 10165 \\
\hline $\mathrm{R}^{2}$ & 0.05 & 0.055 & 0.055 & 0.056 \\
\hline
\end{tabular}

Note. ${ }^{*}, * *$ and $* * *$ are represent the significance level of $10 \%, 5 \%, 1 \%$ respectively.

\subsection{Robustness Test}

First, we replace the financial leverage measurement of explanatory variables. We use the ratio of capital structure $\left(\mathrm{Cs}_{\mathrm{i}, \mathrm{t}-1}\right)$-debt to the owner's equity as an alternative indicator of financial leverage for the robustness test. The empirical results are consistent with the original hypothesis, as shown in table 5. 
Table 5. The robustness test result

\begin{tabular}{|c|c|c|c|c|}
\hline VARIABLES & MODEL(1) & MODEL(2) & MODEL(3) & MODEL(4) \\
\hline $\mathrm{FIR}_{\mathrm{i}, \mathrm{t}-1}$ & $\begin{array}{l}-0.177^{* *} \\
(0.079)\end{array}$ & $\begin{array}{l}-0.111 \\
(0.08)\end{array}$ & $\begin{array}{l}-0.111 \\
(0.08)\end{array}$ & $\begin{array}{l}-0.113 \\
(0.08)\end{array}$ \\
\hline $\mathrm{DR}_{\mathrm{i}, \mathrm{t}-1}$ & $\begin{array}{l}0.039^{* * *} \\
(0.014)\end{array}$ & $\begin{array}{l}0.039^{* * *} \\
(0.014)\end{array}$ & $\begin{array}{l}0.039 * * * \\
(0.014)\end{array}$ & $\begin{array}{l}0.039^{* * *} \\
(0.014)\end{array}$ \\
\hline $\operatorname{SIZE}_{\mathrm{i},-1}$ & $\begin{array}{l}-0.109^{* * *} \\
(0.01)\end{array}$ & $\begin{array}{l}-0.128^{* * *} \\
(0.01)\end{array}$ & $\begin{array}{l}-0.128^{* * *} \\
(0.01)\end{array}$ & $\begin{array}{l}-0.127^{* * *} \\
(0.01)\end{array}$ \\
\hline $\mathrm{ROA}_{\mathrm{i},-1}$ & $\begin{array}{l}-1.316^{* * *} \\
(0.085)\end{array}$ & $\begin{array}{l}-1.215^{* * *} \\
(0.086)\end{array}$ & $\begin{array}{l}-1.216^{* * *} \\
(0.086)\end{array}$ & $\begin{array}{l}-1.22 * * * \\
(0.086)\end{array}$ \\
\hline $\mathrm{AGE}_{\mathrm{i}, \mathrm{t}-1}$ & $\begin{array}{l}-0.01 \\
(0.015)\end{array}$ & $\begin{array}{l}-0.004 \\
(0.015)\end{array}$ & $\begin{array}{l}-0.004 \\
(0.015)\end{array}$ & $\begin{array}{l}-0.006 \\
(0.015)\end{array}$ \\
\hline $\mathrm{CS}_{\mathrm{i}, \mathrm{t}-1}$ & & $\begin{array}{l}0.049 * * * \\
(0.006)\end{array}$ & $\begin{array}{l}0.049 * * * \\
(0.006)\end{array}$ & $\begin{array}{l}0.048 * * * \\
(0.006)\end{array}$ \\
\hline FLSEDU $_{\mathrm{i}, \mathrm{t}-1}$ & & & $\begin{array}{l}-0.045 \\
(0.059)\end{array}$ & $\begin{array}{l}-0.038 \\
(0.059)\end{array}$ \\
\hline $\mathrm{CSx} \times \mathrm{FLSEDU}_{\mathrm{i},-1-1}$ & & & & $\begin{array}{l}-0.114^{* *} \\
(0.054)\end{array}$ \\
\hline CONS & $\begin{array}{l}3.025 * * * \\
(0.264)\end{array}$ & $\begin{array}{l}3.305^{* * *} \\
(0.266)\end{array}$ & $\begin{array}{l}3.309^{* * *} \\
(0.266)\end{array}$ & $\begin{array}{l}3.31 * * * \\
(0.266)\end{array}$ \\
\hline INDUS & CONTROL & CONTROL & CONTROL & CONTROL \\
\hline YEAR & CONTROL & CONTROL & CONTROL & CONTROL \\
\hline $\mathrm{N}$ & 10165 & 10165 & 10165 & 10165 \\
\hline $\mathrm{R}^{2}$ & 0.05 & 0.056 & 0.056 & 0.057 \\
\hline
\end{tabular}

Note. *,** and $* * *$ are represent the significance level of $10 \%, 5 \%, 1 \%$ respectively.

Second, we adjust the asset-liability ratio based on the median of the industry by using the actual asset-liability ratio minus the median of the industry's asset-liability ratio and using $\operatorname{Clev}_{\mathrm{i}, \mathrm{t}-\mathrm{l}}$. The regression results are consistent with those described in table 6 and remain robust.

Table 6. The robustness test result

\begin{tabular}{|c|c|c|c|c|}
\hline VARIABLES & MODEL(1) & MODEL(2) & MODEL(3) & MODEL(4) \\
\hline \multirow{2}{*}{$\mathrm{FIR}_{\mathrm{i}, \mathrm{t}-1}$} & $-0.177 * *$ & -0.099 & -0.1 & -0.101 \\
\hline & $(0.079)$ & $(0.08)$ & $(0.08)$ & $(0.08)$ \\
\hline \multirow{2}{*}{$\mathrm{DR}_{\mathrm{i}, \mathrm{t}-1}$} & $0.039 * * *$ & $0.036 * *$ & $0.036 * *$ & $0.036 * *$ \\
\hline & $(0.014)$ & $(0.014)$ & $(0.014)$ & $(0.014)$ \\
\hline \multirow[t]{2}{*}{$\mathrm{SIZE}_{\mathrm{i}, \mathrm{t}-1}$} & $-0.109 * * *$ & $-0.131 * * *$ & $-0.13 * * *$ & $-0.13 * * *$ \\
\hline & $(0.01)$ & $(0.01)$ & $(0.01)$ & $(0.01)$ \\
\hline \multirow{2}{*}{$\mathrm{ROA}_{\mathrm{i}, \mathrm{t}-1}$} & $-1.316^{* * *}$ & $-1.175 * * *$ & $-1.177 * * *$ & $-1.179 * * *$ \\
\hline & $(0.085)$ & $(0.087)$ & $(0.087)$ & $(0.087)$ \\
\hline \multirow[t]{2}{*}{$\mathrm{AGE}_{\mathrm{i}, \mathrm{t}-1}$} & -0.01 & -0.003 & -0.003 & -0.005 \\
\hline & $(0.015)$ & $(0.015)$ & $(0.015)$ & $(0.015)$ \\
\hline \multirow[t]{2}{*}{ CLEV $_{\mathrm{i}, \mathrm{t}-1}$} & & $0.27 * * *$ & $0.269 * * *$ & $0.269 * * *$ \\
\hline & & $(0.038)$ & $(0.038)$ & $(0.038)$ \\
\hline \multirow[t]{2}{*}{ FLSEDU $_{\mathrm{i}, \mathrm{t}-1}$} & & & -0.043 & -0.037 \\
\hline & & & $(0.059)$ & $(0.059)$ \\
\hline \multirow[t]{2}{*}{$\mathrm{CLEV} \times \mathrm{FLSEDU}_{\mathrm{i}, \mathrm{t}-1}$} & & & & $-0.762 * * *$ \\
\hline & & & & $(0.295)$ \\
\hline \multirow[t]{2}{*}{ CONS } & $3.025 * * *$ & $3.407 * * *$ & $3.411 * * *$ & $3.413 * * *$ \\
\hline & $(0.264)$ & $(0.269)$ & $(0.269)$ & $(0.269)$ \\
\hline INDUS & CONTROL & CONTROL & CONTROL & CONTROL \\
\hline YEAR & CONTROL & CONTROL & CONTROL & CONTROL \\
\hline $\mathrm{N}$ & 10165 & 10165 & 10165 & 10165 \\
\hline $\mathrm{R}^{2}$ & 0.05 & 0.055 & 0.055 & 0.056 \\
\hline
\end{tabular}

Note. ${ }^{*}, * *$ and $* * *$ are represent the significance level of $10 \%, 5 \%, 1 \%$ respectively. 


\section{Discussion}

In much literature exploring the antecedents of strategic change, scholars pay less attention to the impact of corporate financial leverage. Based on the data of A-share manufacturing listed companies in Shanghai and Shenzhen from 2008 to 2018, this paper analyzes the impact of financial leverage on corporate strategic change according to theory of enterprise behavior and expounds on the moderating effect of educational-level faultine strength.

The conclusions are as follows. (1) There is a positive correlation between corporate financial leverage and strategic change. The improvement of financial leverage makes enterprises fall into financial difficulties and bankruptcy risk, and the instability of capital situation has also contributed to excessive attention from the outside world. Under the pressure of their risks and external supervision, enterprises will be more inclined to implement high-intensity strategic changes to win opportunities for survival. (2) Educational-level faultline strength negatively moderates the positive correlation between financial leverage and strategic change. It suggests that educational-level faultline is more likely to trigger differences and conflicts among subgroups than cooperation. When enterprises need to solve the problem of high leverage through strategic change, the strong education-level faultline makes the whole TMT differentiate into subgroups, weakens the integrity of the team, and produces more irrational conflicts among members. This reduces the efficiency of information flow between teams, making it difficult for them to reach a consensus on a resolution, resulting in a decline in decision-making efficiency and a weakening of the intensity of corporate strategic change.

\section{Conclusions}

The results show that there is a positive correlation between corporate financial leverage and strategic change. TMT educational-level faultline strength negatively moderates the positive correlation between corporate financial leverage and strategic change. According to the research conclusions, the following implications can be obtained. First, in terms of risk control, when the internal financial leverage is too high, the TMTs usually adopt a radical strategic change to cope with difficulties, and such strategic decisions also face great uncertainty risks. Therefore, the early warning and prevention mechanism of internal financial leverage should be established to avoid the negative impact of radical change on enterprises. Second, regarding the staffing of TMT, enterprises should optimize the staff matching degree of TMT according to the differences in characteristics such as educational level, and reduce educational-level faultline strength generated by TMT, so that the educational characteristics of decision-making members of the company are more conducive to the formation of cooperation mechanism, rather than conflict, and enhance the efficiency of decision-making of TMT in response to crises.

This study also has certain limitations. First, the sample only selects the data of listed manufacturing enterprises. In the future, we can explore whether the conclusion is universal in the whole industry. Second, the selection of measurement indicators for educational-level faultline strength, we select three indicators of education level, functional background, and tenure. We cannot extrapolate our findings to other types of faultlines that were not measured or commonly observed within the Chinese context, such as variation across religion, as well as variation across "kinship, hometown, or work experiences". Future research may explore other dimensions (e.g., race, culture) that could represent specific demographic faultlines.

\section{Funding}

This research is supported by the Humanities and Social Sciences of Ministry of Education Planning Fund of China (No. 18YJC630093).

\section{Acknowledgements}

The authors would like to thank the reviewers for their valuable comments. Gratitude is also extended to all authors of literatures cited in this article.

\section{References}

Barattieri, A., Moretti, L., \& Quadrini, V. (2021). Banks funding, leverage, and investment. Journal of Financial Economics, 148-171. https://doi.org/10.1016/j.jfineco.2020.06.022

Carton, A. M., \& Cummings, J. N. (2012). A theory of subgroups in work teams. Academy of Management Review, 37(3), 441-470. https://doi.org/10.5465/amr.2009.0322

Chung, Y., Liao, H., Jackson, S. E., Subramony, M., Colakoglu, S., \& Jiang, Y. (2015). Cracking but not breaking: Joint effects of faultline strength and diversity climate on loyal behavior. Academy of Management Journal, 58(5), 1495-1515. https://doi.org/10.5465/amj.2011.0829

Cyert, R. M., \& March, J. G. (1963). A behavioral theory of the firm (pp. 169-187). 
DeAngelo, H., Gonçalves, A. S., \& Stulz, R. M. (2018). Corporate deleveraging and financial flexibility. The Review of Financial Studies, 31(8), 3122-3174. https://doi.org/10.1093/rfs/hhx147

Hambrick, D. C., \& Mason, P. A. (1984). Upper echelons: The organization as a reflection of its top managers. Academy of management review, 9(2), 193-206. https://doi.org/10.5465/amr.1984.4277628

Harford, J., Klasa, S., \& Walcott, N. (2009). Do firms have leverage targets? Evidence from acquisitions. Journal of Financial Economics, 93(1), 1-14. https://doi.org/10.1016/j.jfineco.2008.07.006

Herrmann, P., \& Nadkarni, S. (2013). Managing strategic change: The duality of CEO personality. Strategic Management Journal, 35(9), 1318-1342. https://doi.org/10.1002/smj.2156

Hutzschenreuter, T., \& Horstkotte, J. (2013). Performance effects of top management team demographic faultlines in the process of product diversification. Strategic Management Journal, 34(6), 704-726. https://doi.org/10.1002/smj.2035

Iqbal, N., Xu, J.F., Fareed, Z., Wan, G., \& Ma, L. (2020). Financial leverage and corporate innovation in Chinese public-listed firms. European Journal of Innovation Management. https://doi.org/10.1108/EJIM-04-2020-0161

Kaczmarek, S., Kimino, S., \& Pye, A. (2012). Board task-related faultlines and firm performance: A decade of evidence. Corporate Governance: An International Review, 20(4), 337-351. https://doi.org/10.1111/j.1467-8683.2011.00895

Kadous, K., Proell, C. A., Rich, J., \& Zhou, Y. (2019). It goes without saying: The effects of intrinsic motivational orientation, leadership emphasis of intrinsic goals, and audit issue ambiguity on speaking up. Contemporary Accounting Research, 36(4), 2113-2141. https://doi.org/10.1111/1911-3846.12500

Kim, S., Plosser, M. C., \& Santos, J. A. (2018). Macroprudential policy and the revolving door of risk: Lessons from leveraged lending guidance. Journal of Financial Intermediation, 34, 17-31. https://doi.org/10.1016/j.jfi.2018.01.011

Lau, D. C., \& Murnighan, J. K. (1998). Demographic diversity and faultlines: The compositional dynamics of organizational groups. Academy of management review, 23(2), 325-340. https://doi.org/10.5465/amr.1998.533229

Lee, T., Liu, W. T., \& Yu, J. X. (2021). Does TMT composition matter to environmental policy and firm performance? The role of organizational slack. Corporate Social Responsibility and Environmental Management, 28(1), 196-213. https://doi.org/10.1002/csr.2042

Liu, X., Park, J., Hymer, C., \& Thatcher, S. M. (2019). Multidimensionality: A cross-disciplinary review and integration. Journal of Management, 45(1), 197-230. https://doi.org/10.1177/0149206318807285

MacKay, R. B., \& Chia, R. (2013). Choice, chance, and unintended consequences in strategic change: A process understanding of the rise and fall of NorthCo Automotive. Academy of Management Journal, 56(1), 208-230. https://doi.org/10.5465/amj.2010.0734

Oehmichen, J., Schrapp, S., \& Wolff, M. (2017). Who needs experts most? Board industry expertise and strategic change-a contingency perspective. Strategic Management Journal, 38(3), 645-656. https://doi.org/10.1002/smj.2513

Richard, O. C., Wu, J., Markoczy, L. A., \& Chung, Y. (2019). Top management team demographic-faultline strength and strategic change: What role does environmental dynamism play? Strategic Management Journal, 40(6), 987-1009. https://doi.org/10.1002/smj.3009

Shaw, J. B. (2004). The development and analysis of a measure of group faultines. Organizational Research Methods, 7(1), 66-100. https://doi.org/10.1177/1094428103259562

Tao, Q., Zahid, Z., Mughal, A., \& Shahzad, F. (2020). Does operating leverage increase firm's profitability and bankruptcy risk? Evidence from China's entry into WTO. International Journal of Finance \& Economics. https://doi.org/10.1002/ijfe.2395

Tarakci, M., Ateş, N. Y., Floyd, S. W., Ahn, Y., \& Wooldridge, B. (2018). Performance feedback and middle managers' divergent strategic behavior: The roles of social comparisons and organizational identification. Strategic Management Journal, 39(4), 1139-1162. https://doi.org/10.1002/smj.2745

Thatcher, S. M., \& Patel, P. C. (2012). Group faultlines: A review, integration, and guide to future research. Journal of Management, 38(4), 969-1009. https://doi.org/10.1177/0149206311426187 
Triana, M. D. C., Miller, T. L., \& Trzebiatowski, T. M. (2014). The double-edged nature of board gender diversity: Diversity, firm performance, and the power of women directors as predictors of strategic change. Organization Science, 25(2), 609-632. https://doi.org/10.1287/orsc.2013.0842

Tzabbar, D., \& Margolis, J. (2017). Beyond the startup stage: The founding team's human capital, new venture's stage of life, founder-CEO duality, and breakthrough innovation. Organization Science, 28(5), 857-872. https://doi.org/10.1287/orsc.2017.1152

Van Knippenberg, D., \& Mell, J. N. (2016). Past, present, and potential future of team diversity research: From compositional diversity to emergent diversity. Organizational Behavior and Human Decision Processes, 136, 135-145. https://doi.org/10.1016/j.obhdp.2016.05.007

Zhang, D. (2020). How do firms overcome financial constraint anxiety to survive in the market? Evidence from large manufacturing data. International Review of Financial Analysis, 70, 101503. https://doi.org/10.1016/j.irfa.2020.101503

Zhou, M., Li, K., \& Chen, Z. (2021). Corporate governance quality and financial leverage: Evidence from China. International Review of Financial Analysis, 73, 101652. https://doi.org/ 10.1016/j.irfa.2020.101652

\section{Copyrights}

Copyright for this article is retained by the author(s), with first publication rights granted to the journal.

This is an open-access article distributed under the terms and conditions of the Creative Commons Attribution license (http://creativecommons.org/licenses/by/4.0/). 